\title{
CHARACTERISTICS OF THE FINANCIAL LEASING MARKET IN ALBANIA AND ITS FINANCIAL COSTS
}

\author{
Fatjola Lubonja ${ }^{227}$ \\ Blerina Gjylameti ${ }^{228}$
}

https://doi.org/10.31410/itema.2018.565

\begin{abstract}
The financial leasing is a widely used financing tool all over the world and has seen a significant growth especially in developing countries during recent years. Currently, in the Albanian market, there are nine financial institutions no-banks that offer financial leasing, and about $80 \%$ of all the financial leasing market is focused on the activity of three main companies. Although the financial lease has begun to operate since 2001, in the case of Albania this product has had its difficulties in being recognized from the public, still constituting an alternative of untapped funding to a highly reduced market.

Financial leasing has a lot of unused potential and provides many opportunities for future use, especially for small and medium-sized enterprises, which are the form of business organization having the greatest external financing needs and difficulties. In the case of Albania, SMEs comprise 99.9\% of Albanian businesses and leasing can be the right financing solution for many of them. This article aims to provide through literature review on the financial leasing and through a theoretical and analytical study of the market, an overview of the characteristics and performance of the financial leasing in Albania until March 2018. Except analyzing the latest data of the leasing industry the article will make a comparison of its financial costs compared with bank loans to better understand why this form of financing is still in its first steps in Albania after 17 years.
\end{abstract}

Keywords: financial leasing, financial costs, small and medium enterprises, portfolio, assets.

\section{INTRODUCTION AND LITERATURE REVIEW ON FINANCIAL LEASING}

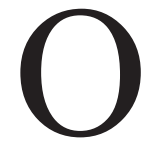
ne of the biggest challenges for a small and medium enterprise that has recently accessed the market remains its ability to find financial support, especially during the first years of life. Inability to finance is one of the most affected and discussed topics in the business world nowadays (CGAP 2013, IMF 2013, and IFC 2009) and is the primary source for their sustainability. Especially in emerging economies and businesses that have just started their activity, access to funding opportunities, remains a key element for their survival and further empowerment. Financial leasing is a form of financing that is being used more and more especially in developed countries by becoming a real financing alternative for new businesses. Based on the lease contract, the lessee may use an asset (s) owned by the lessor. The lessor relies on the tenant's ability to generate sufficient income to pay the lease installments (rather than the tenant's balance sheet or his credit history). The financial lease enables borrowers who do not have a strong borrowing history or do not own collateral to access the use of capital equipment, which is also the case when those businesses are not qualified to obtain traditional lending (Gallardo, 1997; Berger and Udell, 2005). IFC (2009) further

\footnotetext{
${ }^{227}$ Albanian Road Authority; Agricultural University of Tirana, Department of Finance and Accounting, Albania

${ }^{228}$ Member of the Albanian Parliament. University of Tirana, Department of Management, Albania
} 
elaborated the definition of financial lease as a medium-term financial instrument used mainly for the procurement of machinery, equipment, tools and / or property.

The most used definition of financial leasing from a European point of view (used as definition by Leaseeurope) is the one provided by the international accounting standard IAS17 where the lease is defined as an agreement under which the lessor conveys to the lessee the right to use an asset for an agreed period of time in exchange for a payment or series of payments. So simply leasing enables the use of facilities by people who do not own it, thus increasing the ability especially for small and medium-sized businesses with more limited funding opportunities to have more access to short and medium term funding. On the other hand, if we look at Albania in terms of leasing treatment, for the first time in Albanian legislation the financial lease is mentioned in the "Civil Code of the Republic of Albania" and more precisely in Article 849 "Leasing". It states that with the financial lease contract, one party is obliged to make available to the other party for a certain period a movable or immovable asset toward a periodic payment determined in relation to the value of the asset, with the duration of the contract and with other elements defined under the agreement of the parties. Also the asset should have been acquired or constructed by the owner according to the lessor wish that has the right to acquire ownership of the asset at the end of the contract.

Based on empirical studies, it has been studied (Beck, Demirguç-Kunt and Maksimovic) and found that lack of access to external funding is the main obstacle to enterprise growth, especially in the case of small and medium-sized businesses. In many developing countries, the capital market is still underdeveloped, although the case of our country where a finite stock is still lacking, banks in these cases do not want or are unable to take risks when they make loans. Financial institutions prefer in these cases to give loans to larger firms that have a consolidated credit history and significant assets making it even more difficult to find external financing for small and medium-sized businesses especially in the early stages of their creation when the need for external financing is even greater. A number of studies (Schiffer and Weder, 2001, Beck, Demigruc-Kunt, 2006), based on data collected by the firm, have shown that small and medium-sized businesses not only perceive access to external financial resources and cost of credit as the biggest obstacles in relation to large firms but see these factors as barrier factors affecting their performance. Based on a review of the above literature, we can say that the financial lease is a medium-term financing form that will be used especially for small and medium enterprises in the early stages of development, especially in developing countries where alternatives to funding they are even more likely to be found.

\section{FINANCIAL LEASING ACTIVITY IN ALBANIA}

The structure of the banking and financial system at the end of 2017 in Albania consisted of: 16 banks; 31 non-bank financial institutions; 426 foreign exchanges; 13 savings and loan associations; and 1 union of savings and loan associations. The Bank of Albania, based on the Law "On Banks in the Republic of Albania", has the authority to license and supervise banks, non-bank financial institutions, savings and loan associations and their unions, foreign exchange bureaus and banks' representation foreign offices. Since 2001, the Bank of Albania has licensed 13 non-bank financial institutions to engage in financial leasing activity as a single activity, or together with other activities. At present, Albania has about nine financial entities that do not provide banks with financial leases and until December 2017 the total assets of nonbanks are not $1 \%$ of the total assets of the banking system, indicating that the financial lease is a very limited source of funds; unused for the Albanian market. 
In March 2018, gross financial leasing portfolio in Albania for non-bank financial institutions amounted to lek 6.26 billion (approximately Euro 50 million). The subject that dominates the market for years is "Raiffeisen Leasing", which accounts for a total of about $45 \%$ of the financial leasing market for non-bank financial institutions, with a considerable distance from other entities that are ranked behind it (Porsche Leasing - 17\% and Landeslease -16\%). All three of these entities together own $78 \%$ of the financial leasing market in Albania for non-bank financial institutions.

The total number of clients of financial leasing entities in March 2018 amounts to 10,000, which is significantly increased by a single entity "FINAL", which has the crushing number of customers who finance leasing about $70 \%$ of the market. The total number of clients of financial leasing for financial institutions not banks without this entity drops to 2,800 clients. FINAL has an insignificant weight in the market and offers much lower average funding compared to other competitors (around 20,000 lek). If we can see the annual financial leasing market in Albania is limited to as many as 3000 clients per year.

In the chart below we can see more specifically the performance of the financial leasing portfolio of different subjects starting from 2013 (data / 000 lek). From 2013 to 2015 we see a contraction of the financial leasing market in Albania and then from 2015 to 2018 portfolio performance values are played at very low rates. Based on the chart below, the Albanian lending market walks at extremely low rates.

Table 1. Financial lease portfolio performance in 000 ALL for the period 2013-March 2018

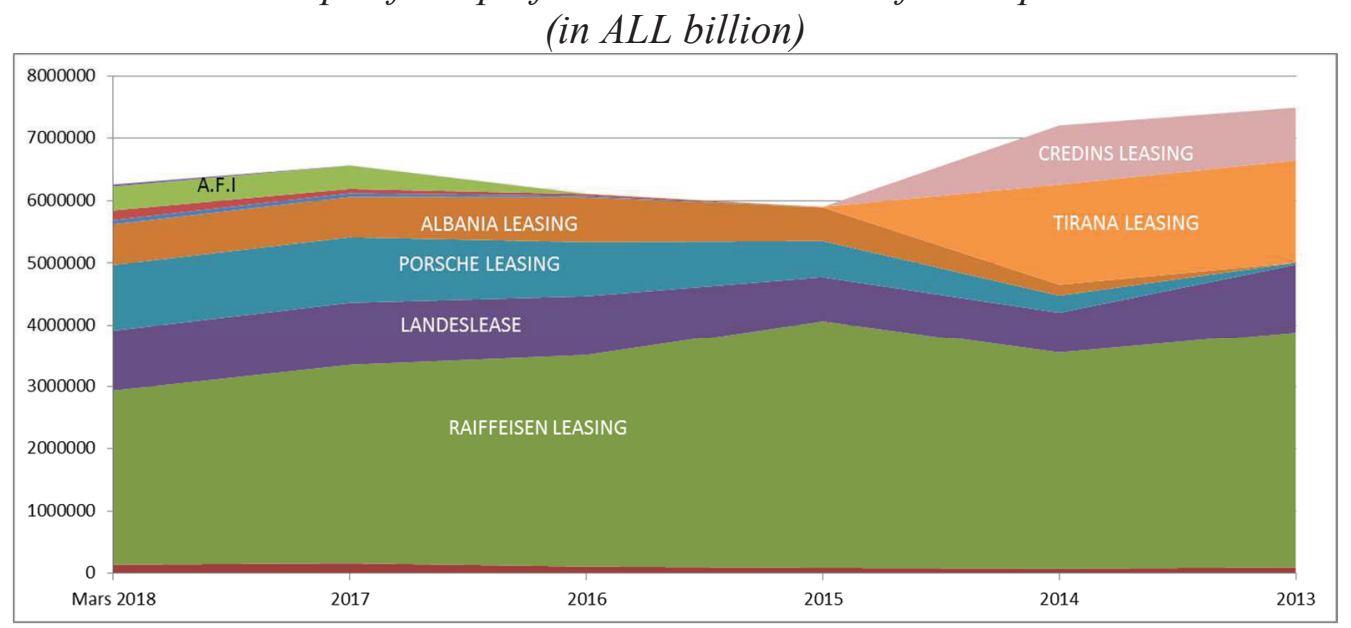

Data processed by the author.

If we see a broader picture of leasing industry across the world, according to the data collected by White Clarke Group in the Annual Lease Report in the Report of 2017, this is the sixth consecutive year after the global financial crisis that the leasing industry has seen growth in new businesses, sales volume and further lease development expectations remain very optimistic. But this is a reality that defines especially the developed countries. If we look further at the pace of financial leasing in the developing countries, the use of this form of financing remains at very low levels and the development of the industry leaves to be desired. 
Graph 2. Leasing percentage in 2016

\section{Leasing percentage (2016)}

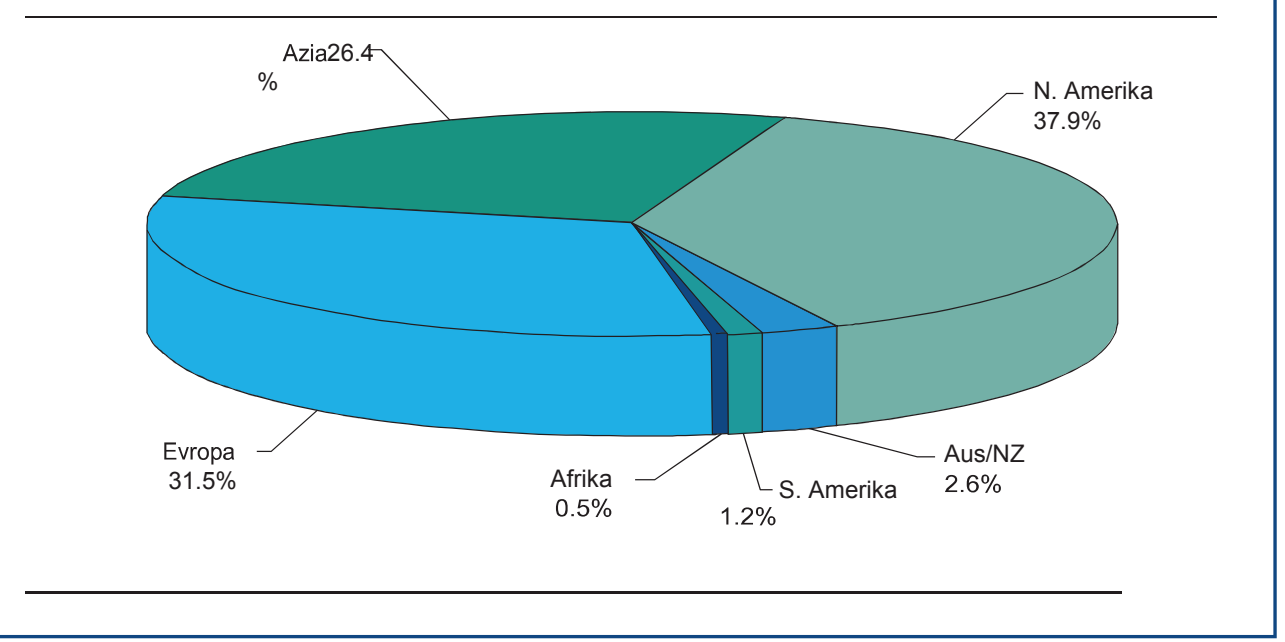

As can be seen in countries like Africa the percentage of leasing use for the year 2016 has fallen to the leasing market from $1 \%$ to only $0.5 \%$ of the world's leasing market (White Clarke Group Global Leasing Report 2017).

In many developing countries, leasing is mostly used by fast growing small and medium-sized businesses that need further funding. (Ayadi 2009).

What is happening in Albania especially in recent years has to do with a reduction in the use of financial leasing, which has always been characterized by a limited market both in the number of clients (about 3000 per year) and in funds funded through leasing. Having much potential and providing untapped opportunities, especially for small and medium-sized businesses that are also the forms of business organization that have the greatest external financing needs and difficulties, leasing can be the right choice for many Albanian businesses.

Those questions that arise naturally after analyzing the financial leasing activity in Albania relate to the reasons for its non-utilization, where unlike other developed countries in Europe and the world leasing has grown in use. On the one hand, bearing in mind the characteristics of the average Albanian businessman also related to the specific historical reasons in which the Albanian business was developed and the connection he has with the idea of being the owner of the property he owns even after 1997 where of pyramid schemes many individuals and businesses lost their properties, we can see that a link between mistrust in the use of leasing since ownership and use of the object in the concrete case are divided. On the other hand, to understand even more clearly the situation and the reasons for the lack of leasing in relation to other forms of financing, we see the leasing financing costs compared to banking lending and which of these forms of financing is more expensive for similar assets being that a higher cost in the leasing case would make it clear at least one of the reasons for its non-use.

The table below summarizes the aggregate interest rate values for all types of subjects, currencies and sectors for bank lending by comparing the latter with the interest rate of financial leasing as a weighted average for the three main entities not banks offering financial leasing in Albania: Raiffeisen Leasing, Porche Leasing and Landelese, which together cover almost 80\% of the entire Albanian lending market in non-bank financial institutions and have a sufficient share of the leasing market in Albania to be accurate in our comparative analysis. The table 
shows a comparison between the weighted average credit values for durable goods compared to the financial lease starting from 2013 until March 2018.

Table 2. Comparison of interest rates between financial leasing and bank credit for durable goods.

\begin{tabular}{|l|l|l|l|l|l|l|}
\hline Year & 2013 & 2014 & 2015 & 2016 & 2017 & 2018 \\
\hline Average lease cost & $8.50 \%$ & $8.00 \%$ & $7.44 \%$ & $7.31 \%$ & $6.22 \%$ & $6.30 \%$ \\
\hline $\begin{array}{l}\text { Average loan cost for durable } \\
\text { goods }\end{array}$ & $10.02 \%$ & $9.58 \%$ & $8.58 \%$ & $7.39 \%$ & $7.10 \%$ & $7.20 \%$ \\
\hline
\end{tabular}

Data processed by the author.

The table data are also shown in the graph below where there is a clear difference between the leasing costs and the bank credit in favor of leasing. The analysis is apparently taking into account those products which are also generally used for financial leasing, which are mainly machines and machineries that are categorized differently as commodity wagers. As we can see graphically from the comparison of the interest rate, leasing is more likely than bank credit to be offered for similar products as the commodities are.

\section{Graph 2. Comparison of interest rates between financial leasing and bank credit for stable} assets.

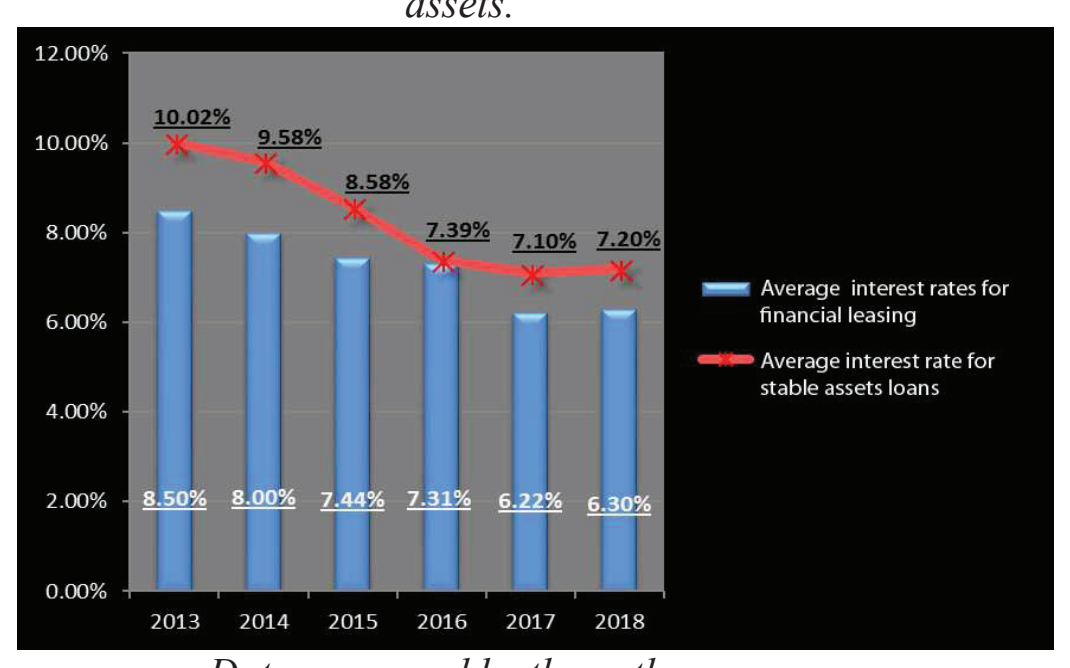

Data processed by the author.

In the table below, the analysis extends even more widely, taking into account interest rates on loans divided into seven different products such as: home loans, durable goods loans, nondurable goods loans, activity loans, loans for individuals and consumer credit, and comparing the latter with the cost of financial leasing where as a benchmark basis are taken the interest rates for the three leading leasing companies in Albania for non-bank institutions that account for $80 \%$ of the financial lending market for these institutions. As we can see from the table, the results of the comparisons regarding the comparison of the leasing costs with bank credit apply in almost all cases to all types of creditworthy goods, except for the case of loans to the house, where the rate the interest in this case is lower than the lease cost. From the following analysis and also based on the study results for the first lease we can say that the average cost of financial leasing is lower than the bank credit. Relying on the literature review and analysis of cost comparison, we see that financial leasing is cheaper than credit despite the ease of application, lack of collateral, and non-registration as debt in accounting books. 
Table 3. Comparison between the financial loan costs for different categories of goods and financial costs of leasing represented by the three main companies in the market

\begin{tabular}{|c|c|c|c|c|c|c|c|c|c|}
\hline Year $-\nabla$ & $\begin{array}{c}\text { Average } \\
\text { interest ra| } \mathbf{}\end{array}$ & $\begin{array}{l}\text { Durable } \\
\text { goods }\end{array}$ & $\begin{array}{l}\text { Non durable } \\
\text { goods }\end{array}$ & $\nabla$ & Mortag $=$ & $\begin{array}{c}\text { Business } \\
\text { loans }\end{array}$ & $\begin{array}{l}\text { Individ } \\
\text { loans }\end{array}$ & $\begin{array}{l}\text { Consum } \\
\text { mer } \\
- \text { loans }\end{array}$ & $\begin{array}{l}\text { Average financial leasing costs } \\
\text { of the three main financial non } \\
\text { banks institution that offer } \\
\text { leasing }\end{array}$ \\
\hline 2013 & 8.33 & 13.31 & 10.02 & & 6.79 & 13.01 & 9.51 & 11.94 & 8.5 \\
\hline 2014 & 7.53 & 10.79 & 9.58 & & 5.71 & 10.94 & 8.61 & 10.62 & 8 \\
\hline 2015 & 6.7 & 9.39 & 8.58 & & 4.84 & 8.36 & 7.58 & 9.37 & 7.44 \\
\hline 2016 & 6.36 & 7.94 & 7.39 & & 3.74 & 7.74 & 7.29 & 8.05 & 7.31 \\
\hline 2017 & 5.76 & 7.7 & 7.1 & & 3.61 & 7.88 & 7.28 & 7.9 & 6.22 \\
\hline 2018 (T1) & 5.71 & 7.54 & 7.2 & & 3.38 & 8.12 & 7.49 & 8.02 & 6.3 \\
\hline
\end{tabular}

Data are gathered and processed by the author

\section{CONCLUSIONS}

The financial leasing activity in Albania is having a period of stagnation and seems to be as a not fully explored opportunity of financing. As we can see in the paper during the analysis of the literature review and of the leasing market:

1. Financial leasing is a medium-term financing form that will be used especially for small and medium enterprises in the early stages of development, especially in emerging economies, whereby alternatives to financing are more and more likely to be found.

2. The financial leasing market in Albania remains limited to a small number of customers, around 10,000 a year, despite the recent developments that this form of financing has received since 2007 in the world.

3. Small and medium enterprises that represent about $99.9 \%$ of the enterprises in the Albanian market would be the one benefiting the most from the use of the financial leasing as an alternative way of financing their business.

4. The level of financing through leasing in Albania shown by the number of clients that use leasing in one year and also by the value of assets that financial institutions no banks do have, illustrates an unused potential, with an inconsiderable financing level toward the banking system.

5. The financing through leasing in Albania, in comparison to the banking loan, is characterized by a lower (interest rate) cost than the banking lending for similar products and in the case of leasing there is no need for collateral.

6. Strengthening the enforceability of the legal framework and the revival of economic activity is expected to bring a positive impact on the development of financial leasing activity too.

7. Enhancing SMEs' awareness of this type of funding and benefits resulting from it will have positive effects on the number of companies using the financial leasing.

\section{REFERENCES}

[1]- [2] CGAP and IFC.2013. Financial Access 2012: Getting to a More Comprehensive Picture. Washington, DC. International Finance Corporation (IFC). 2009. Leasing in Development: Guidelines for Emerging Economies, Washington, DC. International Finance Corporation (IFC). 2011. Global Leasing Toolkit, Washington, Dc.

[3]- [5] Berger, A. and Udell, G. (2005). A More Complete Conceptual Framework for Financing of Small and Medium Enterprises. World Bank Policy Research Working Paper No. 3795. December 2005. Gallardo, J. (1997). Leasing to support small businesses and microenterprises. In: The World Bank. Policy Research Working Paper 1857. December 1997. 
[6] Law no. 7850 "Civil Code of the Republic of Albania", Article 849 "Financial Leasing".

[7] Law no. 9396, dated 12.5.2005 "On financial leasing".

[8] International Accounting Standard 17,16,9 Leases (March 2010 version);

[9] Beck, Thorsten; Demirguc-Kunt, Asli; Levine, Ross, 2000, "A New database on the Structure and Development of the Financial Sector" The World Bank Economic Review (14), 597- 605.

[10] Demirgüç-Kunt, Asli and Vojislav Maksimovic, 1998, Law, Finance, and Firm Growth, Journal of Finance 53, 2107-2137

[11] Beck, T., Demirguc-Kunt, A., Maksimovic, V., 2005. Financial and legal constraints to firm growth: does size matter? J. Financ. 60 (1), 137-177

[12] Ayadi, R. (2009). SME financing in Europe: measures to improve the rating culture under the new banking rules. In: Financing SMEs in Europe. SUERF - the Money and Finance Forum. Vienna.

[13] White Clarke Group Global, Leasing Report 2017

[14] Statistics on Small and Medium Enterprises, 2016, INSTAT

[15] Bank of Albania. (2016). Official Bulletin. Volume 15, No 1.

[16] Bank of Albania. (2010-2017). Supervising Annual Report. Tirana, Albania.

[17] Bank of Albania (2010-2016) Monitoring Annual reports

[18] Brealey, R.A. and Young, C.M., 1980. Debt, Taxes and Leasing - A Note. Journal of Finance, 35, 1245-1250.

[19] European Investment Fund. (2012). The importance of leasing for SME finance. 